\title{
A Descriptive Overview of Standard Precaution Behavior among Clinical Students in the Dental Hospital Universitas Airlangga
}

\author{
Gilang Rasuna Sabdho Wening, Nurnya Aini Dewi, Lidya Martina Santoso, Roesanto Heroesoebekti, \\ Darmawan Setijanto, Agung Sosiawan, Taufan Bramantoro, Titiek Berniyanti and Retno Palupi \\ Department of Dental Public Health, Faculty of Dentistry, Universitas Airlangga, Surabaya - Indonesia \\ gilangrasuna@gmail.com
}

Keywords: Clinical dental student, Behavior, Hand hygiene, Personal protective equipment, Standard precaution

\begin{abstract}
Standard precaution behavior is meant to reduce the risk of transmission through blood-borne pathogens from both recognized and unrecognized sources in dental healthcare services. Hand hygiene and personal protective equipment are two major components of standard precautions that are believed to be the most effective methods to prevent the transmission of pathogens associated with healthcare in dental healthcare workers. The purpose of this study was to investigate the behavior of standard precautions among clinical students in RSGMP FKG Unair and to describe the factors that can influence behavioral activity. This research is a descriptive observational study with a cross-sectional design among 100 clinical students in RSGMP FKG Unair. The data was collected using direct observation, and interviews. The data was then distributed in table form, then analyzed with the SPSS program. The results show that the variables of supervision, facilities, knowledge, treatment types and gender have an odd ratio $>1$, except that supervision and facilities have a p-value $<0.05$, which is p-value 0.001 for supervision and p-value 0.023 for facilities. From the research among 100 clinical students, $54 \%$ of the respondents had a higher score than average. The average score of standard precautions behavior is about $71.8 \%$ or 3.59 out of 5 so it can be concluded that the behavior of standard precautions among clinical students in RSGMP FKG Unair is in need of improvement.
\end{abstract}

\section{INTRODUCTION}

Cross-infection can be defined as the transmission of infectious agents between patients and staff within a clinical environment (Lugito \& Manuel, 2013). Dental health personnel (DHP) are at high risk of exposure to cross-infection with blood-borne pathogens, such as hepatitis B virus (HBV), hepatitis $\mathrm{C}$ virus, and human immunodeficiency virus (HIV), and other viruses and bacteria that colonize the oral cavity and the upper respiratory tract (WHO, 2008). This risk is enhanced by accidental injuries caused by dental instruments during patient treatment. Such infections can be prevented using safety precautions and implementing infection control guidelines in addition to vaccination and proper post-exposure management (Lugito \& Manuel, 2013).

According to the WHO in 2008, two million health workers in the world were exposed to hepatitis $\mathrm{B}$, nine hundred thousand health workers were exposed to hepatitis $\mathrm{C}$, and three hundred thousand health workers were exposed to HIV
(WHO, 2008). In addition, based on the data collected by the Ministry of Health in 2010, 8,786 cases of HIV due to injection were recorded and the risk of HIV to be transmitted from HIV-infected syringes is $0.04 \%$, while the risk of hepatitis B transmission is 27-37\% (Depkes RI, 2008).

Associated with Bloem's theory, health degree is influenced by four factors: environment, health service, heredity, and behavior. So, dentists including clinical dental students need to be aware of disease exposure in the work environment. Standard precaution behavior is meant to reduce the risk of transmission through blood-borne pathogens from both recognized and unrecognized sources in dental healthcare services (Notoatmodjo, 2012).

According to Green, a person's behavior is influenced by a number of factors namely knowledge, attitude, and belief (predisposing factors). In addition, the availability in terms of facilities (enabling factors) and attitude of health workers (reinforcing factors) also support and 
strengthen the formation of behaviour (Notoatmodjo, 2012).

There has been no previous study on the descriptive overview of standard precaution behavior among clinical students in RSGMP FKG UNAIR; hence, this study is expected to comprehend the descriptive overview of standard precaution behavior among clinical students in RSGMP FKG UNAIR as seen from the factors influencing the behavior. Standard precautions to be studied are hand hygiene and use of personal protective equipment, in accordance with the WHO which mentions that hand hygiene and the use of personal protective equipment are the effective first steps in preventing disease transmission in healthcare (WHO, 2008).

\section{MATERIALS AND METHODS}

This research is a descriptive observational research with a cross-sectional design. The number of samples studied were 100 respondents with the sampling technique of random sampling. The data was collected using two methods: interview and behavioral observation. Data collection through interviews was conducted in order to comprehend the knowledge level, gender, semester level, and type of treatment. Meanwhile, observation was conducted in order to determine the behavior, availability of facilities, and supervision by health workers. Clinical dental students in RSGMP FKG UNAIR who were conducting treatment on patients were observed by the researcher without the respondent knowing and then the researcher interviewed the students. The data obtained was then processed and analyzed using the SPSS program.

\section{RESULTS}

Data on the distribution of the respondents' characteristics is shown in Table 1. Table 1 contains the characteristics of 100 respondents; 78 respondents $(78 \%)$ were female. Based on the semester level, the respondents in the $9^{\text {th }}$ semester numbered $53(53 \%)$ and in the $11^{\text {th }}$ semester 47 $(47 \%)$. Based on the type of treatment performed, safe treatment was performed by 79 respondents (79\%) and risky treatment was performed by 21 respondents $(21 \%)$.

Table 1: Distribution of the respondents according to gender, semester level and treatment type.

\begin{tabular}{|l|l|l|l|}
\hline Variables & Category & Amount & Percentage \\
\hline \multirow{2}{*}{ Gender } & Male & 22 & $22 \%$ \\
\cline { 2 - 4 } & Female & 78 & $78 \%$ \\
\hline \multirow{2}{*}{$\begin{array}{l}\text { Semester } \\
\text { Level }\end{array}$} & 9 th Semester & 53 & $53 \%$ \\
\cline { 2 - 4 } & $\begin{array}{l}11 \text { th } \\
\text { Semester }\end{array}$ & 47 & $47 \%$ \\
\hline $\begin{array}{l}\text { Treatment } \\
\text { types }\end{array}$ & Risky & 21 & $21 \%$ \\
\cline { 2 - 4 } & Safe & 79 & $79 \%$ \\
\hline
\end{tabular}

Table 2: Distribution of the respondents according to knowledge level.

\begin{tabular}{|c|c|c|}
\hline Knowledge level & $\begin{array}{c}\text { Frequency } \\
\text { (n) }\end{array}$ & $\begin{array}{c}\text { Percentage } \\
(\%)\end{array}$ \\
\hline$>$ average & 63 & $63 \%$ \\
\hline$\leq$ average & 37 & $37 \%$ \\
\hline
\end{tabular}

From the result, the average knowledge level of the respondents was $76.3 \%$. Furthermore, the distribution of the respondents' knowledge level was categorized into above average knowledge and less than or equal to average knowledge. The following is the distribution of respondents based on the knowledge level of the standard precaution.

Table 3: Distribution of the respondents according to availibility of facilities and supervision.

\begin{tabular}{|c|l|c|c|}
\hline Variables & Category & Amount & Percentage \\
\hline \multirow{2}{*}{$\begin{array}{c}\text { Availability } \\
\text { of facilities }\end{array}$} & Sufficient & 38 & $38 \%$ \\
\cline { 2 - 4 } & Insufficient & 62 & $62 \%$ \\
\hline \multirow{3}{*}{ Supervision } & Conducted & 22 & $22 \%$ \\
\cline { 2 - 4 } & $\begin{array}{l}\text { Not } \\
\text { conducted }\end{array}$ & 78 & $78 \%$ \\
\hline
\end{tabular}

Table 3 describes the distribution of the respondents according to the availability of standard precaution facilities and supervision by health workers. Based on the table, it is seen that the majority of the respondents $(62 \%)$ worked within a cubicle with insufficient facilities. Similarly, the majority of the respondents $(78 \%)$ worked without any supervision from health workers.

Table 4: Distribution of the respondents according to standard precaution behavior among clinical students in RSGMP FKG Unair.

\begin{tabular}{|l|c|c|}
\hline Standard Precaution Behavior & $\begin{array}{c}\text { Yes } \\
(\%)\end{array}$ & $\begin{array}{c}\text { No } \\
(\%)\end{array}$ \\
\hline Hand hygiene & $56 \%$ & $44 \%$ \\
\hline
\end{tabular}




\begin{tabular}{|ll|c|c|}
\hline $\begin{array}{l}\text { Using personal protective } \\
\text { equipment - masks }\end{array}$ & $95 \%$ & $5 \%$ \\
\hline $\begin{array}{l}\text { Using personal protective } \\
\text { equipment - gloves }\end{array}$ & $99 \%$ & $1 \%$ \\
\hline $\begin{array}{l}\text { Using personal protective } \\
\text { equipment - lab coats }\end{array}$ & $100 \%$ & $0 \%$ \\
\hline $\begin{array}{l}\text { Using personal protective } \\
\text { equipment - safety glasses or } \\
\text { goggles }\end{array}$ & $9 \%$ & $91 \%$ \\
\hline Average & & $\begin{array}{c}71.8 \\
\%\end{array}$ & $28.2 \%$ \\
\hline
\end{tabular}

From the result, the average score on standard precaution behavior of the respondents was $71.8 \%$. Moreover, the distribution of respondents' behavior was categorized into above average behavior and less than or equal to average behavior. The following is the distribution of the respondents based on standard precaution behavior.

Table 5: Distribution of the respondents according to category of standard precaution behavior among clinical students in RSGMP FKG UNAIR.

\begin{tabular}{|c|c|c|}
\hline $\begin{array}{c}\text { Behavior } \\
\text { score }\end{array}$ & $\begin{array}{c}\text { Frequency } \\
\text { (n) }\end{array}$ & $\begin{array}{c}\text { Percentage } \\
(\%)\end{array}$ \\
\hline$>$ average & 54 & $54 \%$ \\
\hline$\leq$ average & 46 & $46 \%$ \\
\hline
\end{tabular}

Based on the table, it is seen that the majority of the respondents $(54 \%)$ had above average standard precaution behavior.

Table 6: Distribution of the respondents according to Gender, Semester Level, and Types of Treatment related to Standard Precaution.

\begin{tabular}{|c|c|c|c|c|}
\hline \multirow{2}{*}{ Variables } & \multirow{2}{*}{ Categories } & \multicolumn{2}{|c|}{ Behavior } & \multirow{2}{*}{$\begin{array}{c}\text { P Value } \\
\text { Odd } \\
\text { Ratio } \\
\end{array}$} \\
\hline & & $\begin{array}{c}\leq \\
\text { Average }\end{array}$ & $\begin{array}{c}> \\
\text { Average }\end{array}$ & \\
\hline \multirow[b]{2}{*}{ Gender } & Female & $\begin{array}{c}36 \\
(46.2 \%) \\
\end{array}$ & $\begin{array}{c}42 \\
(53.8 \%) \\
\end{array}$ & \multirow{2}{*}{$\begin{array}{c}\text { P Value } \\
0.954 \\
\\
\text { Odd } \\
\text { Ratio } \\
1.029\end{array}$} \\
\hline & Male & $\begin{array}{c}10 \\
(45.5 \%)\end{array}$ & $\begin{array}{c}12 \\
(54.5 \%)\end{array}$ & \\
\hline \multirow{3}{*}{$\begin{array}{l}\text { Semester } \\
\text { level }\end{array}$} & $\begin{array}{c}9^{\text {th }} \\
\text { Semester }\end{array}$ & $\begin{array}{c}23 \\
(43.4 \%) \\
\end{array}$ & $\begin{array}{c}30 \\
(56.6 \%) \\
\end{array}$ & \multirow{3}{*}{$\begin{array}{c}\text { P Value } \\
0.579 \\
\\
\text { Odd } \\
\text { Ratio } \\
0.800\end{array}$} \\
\hline & $\begin{array}{c}11^{\text {th }} \\
\text { Semester }\end{array}$ & $\begin{array}{c}23 \\
(48.9 \%) \\
\end{array}$ & $\begin{array}{c}24 \\
(51.1 \%)\end{array}$ & \\
\hline & Risky & $\begin{array}{c}7 \\
(46.0 \%)\end{array}$ & $\begin{array}{c}14 \\
(73.3 \%)\end{array}$ & \\
\hline
\end{tabular}

From the table, it can be seen that the female and male respondents equally had above average behavior as well as seen from semester level; $9^{\text {th }}$ semester and $11^{\text {th }}$ semester students equally had above average behavior. If seen from type of treatment, the respondents with risky treatment had above average behavior compared to the respondents with safe treatment.

However, the result of $\mathrm{p}$ value for the three variables > 0.005 meaning that gender, semester level, and type of treatment were not significantly related to the standard precaution behavior among clinical students in RSGMP FKG UNAIR.

Table 7: Distribution of the respondents according to Knowledge Level, Availability of facilities, and Supervision by health workers related to Standard Precaution Behavior.

\begin{tabular}{|c|c|c|c|c|}
\hline \multirow{2}{*}{ Variables } & \multirow{2}{*}{ Categories } & \multicolumn{2}{|c|}{ Behavior } & \multirow{2}{*}{$\begin{array}{c}\text { P Value } \\
\text { Odd } \\
\text { Ratio }\end{array}$} \\
\hline & & $\begin{array}{c}\leq \\
\text { Average }\end{array}$ & $\begin{array}{c}> \\
\text { Average }\end{array}$ & \\
\hline \multirow[b]{2}{*}{$\begin{array}{l}\text { Knowledge } \\
\text { level }\end{array}$} & $\leq$ average & $\begin{array}{c}21 \\
(56.8 \%)\end{array}$ & $\begin{array}{c}16 \\
(43.2 \%)\end{array}$ & $\begin{array}{c}\text { P Value } \\
0.098\end{array}$ \\
\hline & $>$ average & $\begin{array}{c}25 \\
(39.7 \%)\end{array}$ & $\begin{array}{c}38 \\
(60.3 \%)\end{array}$ & $\begin{array}{c}\text { Odd } \\
\text { Ratio } \\
1.995\end{array}$ \\
\hline \multirow[b]{2}{*}{$\begin{array}{l}\text { Availabilit } \\
\text { y of } \\
\text { facilities }\end{array}$} & $\begin{array}{c}\text { Insufficie } \\
\text { nt }\end{array}$ & $\begin{array}{c}34 \\
(54.8 \%)\end{array}$ & $\begin{array}{c}28 \\
(45.2 \%)\end{array}$ & $\begin{array}{c}\mathrm{P} \text { value } \\
0.023\end{array}$ \\
\hline & Sufficient & $\begin{array}{c}12 \\
(31.6 \%)\end{array}$ & $\begin{array}{c}26 \\
(68.4 \%)\end{array}$ & $\begin{array}{c}\text { Odd } \\
\text { Ratio } \\
2.631\end{array}$ \\
\hline \multirow{2}{*}{$\begin{array}{c}\text { Supervisio } \\
\mathrm{n} \text { by health } \\
\text { workers }\end{array}$} & $\begin{array}{c}\text { Not } \\
\text { conducte } \\
\text { d }\end{array}$ & $\begin{array}{c}43 \\
(55.1 \%)\end{array}$ & $\begin{array}{c}35 \\
(44.9 \%)\end{array}$ & $\begin{array}{c}\text { P value } \\
0.001\end{array}$ \\
\hline & $\begin{array}{c}\text { Conducte } \\
\mathrm{d}\end{array}$ & $\begin{array}{c}3 \\
(13.6 \%)\end{array}$ & $\begin{array}{c}19 \\
(86.4 \%)\end{array}$ & $\begin{array}{c}\text { Odd } \\
\text { Ratio } \\
7.781 \\
\end{array}$ \\
\hline
\end{tabular}

Based on the table, it is shown that the respondents with above average knowledge had above average behavior; otherwise the respondents with less than or equal to average knowledge had less than average to average behavior.

From the availability of facilities, the respondents with insufficient facilities had less than average behavior; otherwise the respondents with sufficient facilities had above average behavior. Similarly, the respondents with supervision by health workers had above average behavior compared to the respondents without supervision by health workers.

Of the three variables, the $\mathrm{p}$ value for the availability of facilities and supervision $<0.005$ meaning that the availability of facilities and supervision by health workers significantly correlated with the standard precaution behavior among clinical students in RSGMP FKG UNAIR. 


\section{DISCUSSION}

The result of the research shows that the average standard precaution behavior was $71.8 \%$ or 3.59 of the total value of 5 with the standard deviation of 0.648 . Such score is lower than the standard set by the WHO, whereas hand hygiene and the use of personal protective equipment are the most important components in terms of standard precautions which is the basis for prevention and control of disease transmission in health services.

In addition, 54 out of 100 respondents had above average behavior in terms of implementing standard precautions. This number is somewhat small, given the risks faced. The result of the study conducted by Ningrum shows that the compliance level among clinical students in RSGMP UMY regarding the use of personal protective equipment was $91.7 \%$ as well as Setiana's which found the level of infection prevention in UNDIP students of $98.1 \%$. Compared to the previous studies, it can be stated that the behavior of prevention and control of disease among clinical students in RSGMP FKG UNAIR remains lacking.

Lack of such behavior is seen from the minimal use of personal protective equipment, namely safety glasses or goggles (Table 4). The result of the study was obtained from 22 risky treatments, 9 of which used safety glasses during the procedure. Safety glasses are worn during the treatment of scaling, curettage, and exodontias due to the fact that such treatments are prone to aerosol contamination and sprinkling of body fluids (blood and saliva). Furthermore, safety glasses were mostly worn by females (6 respondents) rather than males (3 respondents). This is due to the fact that females have the characteristics of maintaining their physical appearance, especially the face, so that they pay more attention to the work environment.

Some students performed risky treatment without using safety glasses; this is due to the lack of selfawareness of the students regarding the importance of maintaining personal safety during work. Besides safety glasses or goggles, hand hygiene behavior is also the standard precaution behavior which is still underestimated by clinical students (Table 4). This is possibly caused by insufficient hand hygiene facilities (Table 3). The lack of such facilities includes the unavailability of antiseptic soap in each cubicle and faucets which do not function, so that the students are reluctant to wash their hands after the treatment.

According to Lawrence Green's theory, adequate knowledge as a predisposing factor should be followed by good and right behavior. However, as a matter of fact, out of 63 respondents with above average knowledge, 25 had less than average behavior (Table 7). This may be due to the lack of sufficient facilities as it is known that the availability of facilities as an enabling factor also influences respondents' behavior. If students with above average knowledge are not supported by the availability of sufficient facilities, it will result in less than average behavior.

The relation between facilities and standard precaution behavior is shown by the $p$ value of 0.023 and odds ratio of 2.631 meaning that if the facilities are sufficient, the respondents have the opportunity of 2.631 times in order to behave above average compared to the respondents with insufficient facilities.

The result is in accordance with Lawrence Green's theory stating that a person's behavior is influenced by enabling factors, such as the availability of facilities. Without sufficient facilities, one will not be able to apply good behavior. Similar to this study, in implementing the standard precaution behavior as an effort to prevent disease in the work environment, sufficient facilities are required. Clinical students tend to implement standard precautions as an effort to avoid disease transmission if hand hygiene facilities are available in the workplace. In addition, the availability of facilities must also be supported with sufficient facilities, so that they are able to improve good behavior in implementing standard behavior.

Besides facility factors, the lack of supervision by health workers regarding standard precautions also affects student behavior. Such factor plays an important role in the standard precaution behavior among clinical students in RSGMP FKG UNAIR which means that if behavior is explained through the supervision of standard precautions, there was a difference between the supervised and the unsupervised respondents. This is supported by the statistical test result of the $\mathrm{p}$ value which is 0.001 and odds ratio which is 7.781 meaning that if supervision is provided, the respondents have 7.781 more chances to behave above average compared to unsupervised respondents (Table 7).

The purpose of supervision is to eliminate or minimize unexpected behavior. Through supervision, the students will behave in accordance with the procedure in terms of implementing standard precautions as an effort to prevent disease in the workplace. This is due to the fear or pressure (enforcement) in the students of punishment if they do not perform standard precautions. 
Such emphasis approach leads to a faster impact on behavioral change, but generally such behavioral change is not sustainable due to the fact that such behavior is not based on a high level of knowledge and awareness regarding the purpose of the behavior. Looking at the result of the study (Table 5.3), the majority of the respondents remained working without supervision by health workers, whereas the lack of supervision can possibly lead to the risk of degraded behavior, and vice versa.

\section{CONCLUSIONS}

From the result of the study on 100 clinical students, it can be concluded that $54 \%$ of the respondents were above average. With the average standard precaution behavior of $71.8 \%$ or 3.59 out of 5 , this is considered low. Thus, the standard precaution behavior among clinical students in RSGMP FKG UNAIR needs improvement.

\section{REFERENCES}

Center for Disease Control and Prevention. 2003. Guidline for Infection Control in Dental-Health-Care Settings. MMWR 2003;

Depkes, RI. 2008. Pedoman Pencegahan dan Pengendalian Infeksi di Rumah Sakit dan Fasilitas Pelayanan Kesehatan Lainnya. Jakarta: Depkes RI, hal 2-11.
Kemenkes, R1. 2012. Standar pencegahan dan pengendalian infeksi pelayanan kesehatan gigi dan mulut di fasilitas pelayanan kesehatan. Jakarta: Kementerian Kesehatan RI.

Kohli A, Puttaiah R. 2007. Dental infection control and occupational safety for oral health professionals. Edisi 1. New Delhi: Dental Council of India, hal. 1-50.

Lugito, Manuel DH. 2013. Kontrol Infeksi dan Keselamatan Kerja dalam Praktek Kedokteran Gigi. Jurnal PDGI Volum 62, No 1, hal 24-30.

McGovern, Patricia M., Donald Vesley, Laura Kochevar, Robyn R.M. Gershin, Frank S. Shame, Elizabeth Anderson. 2000. Factors Affecting Universal Precautions Compliance, Journal of Bussiness and Psychology Vol.15 No. 1, Fall. www.proquest.com

Ningrum 2014. Kepatuhan penggunaan APD pada mahasiswa UMY. Jogja: Universitas Gajah Mada, hal $1-18$.

Notoatmodjo, S. 2012. Promosi Kesehatan dan Perilaku Kesehatan. Edisi Revisi XII, Rineka Cipta, Jakarta.

Permenkes RI, 2004. No. 1173/MENKES/PER/X/2004. Tentang Rumah Sakit Gigi dan Mulut. Bab II. Pasal 5. Hal 4.

Putra, Moch Udin Kurnia. 2012. Hubungan Tingkat Pengetahuan dan Sikap dengan Perilaku Penggunaan Alat Pelindung Diri pada Mahasiswa Profesi Fakultas Ilmu Keperawatan Universitas Indonesia. Depok: Universitas Indonesia.

Setiana, D. 2011. Pengetahuan, Sikap dan Praktik Mahasiswa Fakultas Kedokteran Terhadap Pencegahan Infeksi. Semarang: Universitas Diponegoro, hal 1-18.

WHO. 2008. Practical Guidlines for Infection Control in Health Care Facility. India: WHO Regional office South East Asia. 